\title{
Integrated Evaluation of New Fungicides and Bioagents for the Management of Banded Leaf and Sheath Blight of Maize
}

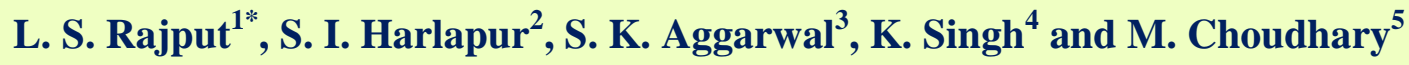 \\ ${ }^{1}$ Division of Crop Protection, ICAR-Indian Institute of Soybean Research, \\ Indore-452001, Madhya Pradesh, India \\ ${ }^{2}$ Department of Plant Pathology, AICRP on Maize, University of Agricultural Sciences, \\ Dharwad 580 005, Karnataka, India \\ ${ }^{3}$ Division of Crop Protection, ICAR-Indian Institute of Maize Research, \\ Ludhiana-141004, Punjab, India \\ ${ }^{4}$ Division of Plant Pathology, ICAR-National Bureau of Plant Genetic Resources Regional \\ Station, Jodhpur-342003, India \\ ${ }^{5}$ Division of Plant Pathology, ICAR-National Research center for Integrated Pest \\ Management, New Delhi-110012, India \\ *Corresponding author
}

\begin{abstract}
A B S T R A C T
\section{Keywords}

Foliar spray, Kresoxim-methyl, Pseudomonas fluorescens, $R$. solani f.sp., sasakii and seed treatment

Article Info

Accepted:

20 August 2020

Available Online:

10 September 2020

Biocontrol agents along with fungicides were evacuated in field condition to assess the most appropriate management strategy for management of banded leaf and sheath blight of maize caused by Rhizoctonia solani f. sp. sasakii. Two biocontrol agents and four fungicides viz., T. harzianum, Pseudomonas fluorescens, Carboxin 36.5\% + Thiram 36.5\% DS, Tebuconazole 50WG, Mencozeb 50\% + Carbendazim 25\% WS and Carbendazim 50 WP respectively were used as seed treatments and three new strobilurins fungicide such as Kresoxim-methyl 44.3 SC, Pyraclostrobin 23.6 EC and Pyraclostrobin $5+$ Metiram 55 WG were used for twice foliar spray at 30 and 45 days after sowing. Seed treatment with $P$. fluorescens found effective against $R$. solani f.sp. sasakii with enhanced maize grain yield, fodder yield and 100 seed weight, followed by Carboxin $36.5 \%+$ Thiram $36.5 \%$ DS and Carbendazim 50 WP @ $2.5 \mathrm{~g} / \mathrm{kg}$ of seed (41.2\%). All three strobilurins fungicides were found effective against $R$. solani f. sp. sasakii, where as Kresoxim-methyl found most effective as for foliar spray. Seed treatment with P. fluorescens @ $10 \mathrm{~g} / \mathrm{kg}$ of seed followed by two spray of Kresoxim-methyl 44.3 SC found best management strategy against $R$. solani f.sp. sasakii which selected in enhanced maize grain yield, fodder yield and 100 seed weight followed by seed treatment with P. fluorescens @ $10 \mathrm{~g} / \mathrm{kg}$ of seed and two foliar spray of Pyraclostrobin 23.6 EC.
\end{abstract}

\section{Introduction}

Banded leaf and sheath blight (BLSB) of maize is a devastating disease in India. BSLB is caused by Rhizoctonia solani f. sp. sasakii is a soil borne multi-host fungus. Due to several host range and high diversity, development of resistance genotype is very 
difficult so unavailability of resistance genotype leads to application of chemical or biocontrol agent in management of BLSB disease (Rajput and Harlapur 2016). BLSB disease was economical important disease with nearly 50 percemt of severity in North Karnataka especially in heavy rainfall area (Rajput and Harlapur 2014). Average 23.9 to 31.9 percentage of avoidable yield loss was reported in ten cultivars of maize in India (Lal et al., 1980). The disease was well established in India and other part of world (Rajput and Harlapur 2015). Various biocontrol agents such as Trichoderma viride T. harzianum and Pseudomonas fluorescens found effecitive in management of $R$. solani f.sp. sasakii in both in vitro and in vivo condition (Rajput and Harlapur 2015 Rajput et al., 2016a), where as propiconazole and carbendazim also found effective in both in vitro and in vivo condition (Rajput and Harlapur 2015 Rajput et al., 2016b). Seed treatment with $P$. fluorescens $(10 \mathrm{~g} / \mathrm{kg}$ of seed) followed by application of propiconazole $(0.1 \%)$ reduced BLSB disease severity by 68.90 percent as compared to control and increase grain and fodder yield by $40.72 \%$ and $44.68 \%$ (Rajput and Harlapur 2015). Seed treatment with carbendazim $(2 \mathrm{~g} / \mathrm{kg}$ of seed) reduced BLSB disease severity by 68.00 percent as compared to control, where as foliar application reduced disease severity 25.70 percent as compared to control (Akhtar et al., 2011). Mustard crop used as biofumigation of soil combined with seed treatment, soil drenching and foliar spray of $P$. fluorescens reduced BLSB disease severity and viability of inoculums (Madhavi and Devi, 2018). Foliar application of validamycin $(0.2 \%)$ reduced BLSB disease severity and enhanced yield of maize as compared to control (Venkateswarlu and Beura 2020). Foliar application of validamycin $(0.1 \%)$ and trifloxystrobin + tebuconazole $(0.05 \%)$ were reduced the severity of BLSB and effectively manage the disease (Malik et al., 2018). Ram (2016) found Kresoxim-methyl as effective fungicide for management of $R$. solani in rice field. Similarly, Kumar and Ladha (2011) and Biswas (2012) also found foliar spray of Kresoxim- effective against $R$. solani in rice field. Since most of research tried strobilurins compound for rice crop rather than maize crop against $R$. solani. BLSB occurred in major maize growing area and cause economic impact of farmer, therefore a field experiment was conducted to evaluate the efficacy of new strobilurins fungicides along with bio-control agents as foliar spray and seed treatment agents for effective management of BLSB caused by $R$. solani f.sp. sasakii in maize.

\section{Materials and Methods}

\section{Biological materials}

To evaluate efficacy of new fungicide and biocontrol agents against management of BLSB of maize a maize hybrid DKC-8101 was selected which showed moderate resistance against BLSB of maize. $P$. fluorescens and T. harzianum cultures were obtained from Department of Microbiology, UAS, Dharwad. R. solani f. sp. sasakii was isolated from Saidapur Farm, Main Agricultural Research Station (MARS), Dharwad.

\section{Field experiment}

In split plot design new fungicides and biocontrol agents were evaluated at MARS, Saidapur farm, Dharwad during kharif season of 2012 with three replications. Maize hybrid DKC-8101 seeds were treated with two biocontrol agents and four fungicides viz., $T$. harzianum @ $10 \mathrm{~g} / \mathrm{kg}$ of seed, P.fluorescens @ $10 \mathrm{~g} / \mathrm{kg}$ of seed, Carboxin 36.5\% + Thiram $36.5 \%$ DS @ $2.5 \mathrm{~g} / \mathrm{kg}$ of seed, Tebuconazole $50 \mathrm{WG} @ 1.5 \mathrm{~g} / \mathrm{kg}$ of seed, Mencozeb 50\% + Carbendazim 25\% WS @ $2.5 \mathrm{~g} / \mathrm{kg}$ of seed 
and Carbendazim 50 WP @ 2.5 g/ kg of seed along with gum as sticker. Treated seed were dried in plain paper for four hours in shaded area and sown immediately after drying. The field experiment was conducted under irrigated condition under red soil with recommended dose of fertilizers, while insect management practices were followed as per recommendation of UAS, Dharwad. Maize hybrid DKC-8101 seeds were sowed in 6 rows with $60 \mathrm{~cm} \times 20 \mathrm{~cm}$ in plot area of 9.0 $\mathrm{m}^{2}$. Foliar spray of three fungicides viz., Kresoxim-methyl 44.3 SC @ 1 g/l of water, Pyraclostrobin 23.6 EC @ 1 g/l of water and Pyraclostrobin 5+ Metiram 55 WG @ 2 g/l of water were sprayed twice 30 and 45 days after sowing. $R$. solani f.sp. sasakii was multiplied on autoclaved sorghum grain and mixed with soil 400 gm of infected sorghum grain per meter square into top $5 \mathrm{~cm}$ of soil depth. Same 2-3 infected sorghum grain placed gently between rind and sheath blight in 30 days old plants.

Disease severity was observed at silk formation stage with 1-5 disease rating scale (Ahuja and Payak, 1983). Percentage Disease Index (PDI) was calculated with formula, PDI $=($ Sum of indivisula rating of leaves $\times 100) /$ (number of leaves observed $\times$ maximum scale), whereas percentage disease control was calculated based on disease observed in untreated control plot. Yield of grain and fodder was also calculated on basis of this enhancement in yield of both grain and fodder yield was also calculated, whereas 100 seed weight also calculated. The data was transformed to arc sine values and analyzed statistically.

\section{Results and Discussion}

Significant differences were observed among the treatments for PDI. The PDI was significantly different for seed treatment chemicals and bio-control agents and chemicals of foliar applications (Table 1). PDI was ranging from $43.3 \%$ to $40.0 \%$ by using seed treatments. Minimum PDI was observed as $40.0 \%$ after seed treatment with P.fluorescens @ $10 \mathrm{~g} / \mathrm{kg}$ of seed over the control $(46.9 \%)$ followed by Carboxin $36.5 \%$ + Thiram 36.5\% DS @ $2.5 \mathrm{~g} / \mathrm{kg}$ of seed (41.2\%) and Carbendazim 50 WP @ $2.5 \mathrm{~g} / \mathrm{kg}$ of seed $(41.2 \%)$. PDI was ranging from $37.14 \%$ to $34.84 \%$ by foliar application of new fungicides. Minimum PDI $34.8 \%$ was observed after foliar application of Kresoximmethyl 44.3 SC @ 1 g/l of water over the control (61.1\%) followed by Pyraclostrobin 23.6 EC @ 1 g/l of water $(36.1 \%)$. PDI was significant differed for interaction effect of seed treatment and foliar spray also.

Minimum PDI $32.3 \%$ was observed with seed treatment with P.fluorescens @ $10 \mathrm{~g} / \mathrm{kg}$ of seed followed by two spray of Kresoximmethyl 44.3 SC @ 1 g/l of water over the control $(65.4 \%)$ was statistically higher with seed treatment with P. fluorescens @ $10 \mathrm{~g} / \mathrm{kg}$ of seed followed by two spray of Pyraclostrobin 23.6 EC @ 1 g/l of water (33.5\%), seed treatment with Carboxin 36.5\% + Thiram 36.5\% DS @ $2.5 \mathrm{~g} / \mathrm{kg}$ of seed followed by two spray of Pyraclostrobin 23.6 EC @ $1 \mathrm{~g} / \mathrm{l}$ of water $(33.8 \%)$ and seed treatment with Carbendazim 50 WP @ $2.5 \mathrm{~g} /$ $\mathrm{kg}$ of seed followed by two spray of Pyraclostrobin 23.6 EC @ 1 g/l of water (33.8\%). Maximum BLSB disease was reduce by seed treatment of P.fluorescens @ $10 \mathrm{~g} / \mathrm{kg}$ of seed $(38.91 \%)$ over than control (28.36\%), where as foliar spray of Kresoxim-methyl 44.3 SC @ $1 \mathrm{~g} / 1$ of water $(46.72 \%)$ was also reduced maximum disease over the control (Table 2). The interaction of seed treatments with foliar application, P. fluorescens @10 $\mathrm{g} / \mathrm{kg}$ of seed followed by two spray of Kresoxim-methyl 44.3 SC @ 1 g/l of water reduce BLSB by $50.61 \%$ over the control $(0.00 \%)$ followed by $P$. fluorescens @ 10 $\mathrm{g} / \mathrm{kg}$ of seed followed by two spray of 
Pyraclostrobin 23.6 EC @ 1 g/l of water (48.78\%) over the control.

The grain yield of maize was also significantly different for seed treatment chemicals and bio-control agents and chemicals of foliar applications (Table 3). Grain yield of maize was ranging $70.54 \mathrm{q} / \mathrm{ha}$ to $58.60 \mathrm{q} / \mathrm{ha}$ after using either seed treatment or foliar application or both with fungicide or biocontrol agent or both. Seed treatment has significant difference on maize yield. Maximum maize grain yield was observed as $67.31 \mathrm{q} / \mathrm{ha}$ after seed treatment with $P$. fluorescens @10 g/kg of seed over the control $(62.32 \mathrm{q} / \mathrm{ha})$ followed by Carboxin $36.5 \%$ + Thiram 36.5\% DS @ $2.5 \mathrm{~g} / \mathrm{kg}$ of seed (66.24 q/ha) and Carbendazim 50 WP @ $2.5 \mathrm{~g} / \mathrm{kg}$ of seed $(66.99 \mathrm{q} / \mathrm{ha})$. Grain yield of maize was ranging $68.13 \mathrm{q} / \mathrm{ha}$ to $66.01 \mathrm{q} / \mathrm{ha}$ by using foliar application one new fungicide. Maximum maize grain yield was observed as $68.13 \mathrm{q} / \mathrm{ha}$ after foliar application of Kresoxim-methyl 44.3 SC @ 1 g/l of water over the control $(59.47 \mathrm{q} / \mathrm{ha})$ was statistically on par with Pyraclostrobin 23.6 EC @ 1 g/l of water $(67.34 \mathrm{q} / \mathrm{ha})$. Grain yield of maize was significant differed for interaction effect of seed treatment and foliar spray also. Maximum maize grain yield $70.54 \mathrm{q} / \mathrm{ha}$ was observed with seed treatment with $P$. fluorescens@10 g/kg of seed followed by two spray of Kresoxim-methyl 44.3 SC @ 1 $\mathrm{g} / \mathrm{l}$ of water over the control (56.15 q/ha) was statistically on par with seed treatment with $P$. fluorescens @ $10 \mathrm{~g} / \mathrm{kg}$ of seed followed by two spray of Pyraclostrobin 23.6 EC @ 1 g/l of water $(69.75 \mathrm{q} / \mathrm{ha})$, seed treatment with Carboxin 36.5\% + Thiram 36.5\% DS @ 2.5 $\mathrm{g} / \mathrm{kg}$ of seed followed by two spray of Pyraclostrobin 23.6 EC @ 1 g/l of water $(69.04 \mathrm{q} / \mathrm{ha})$. Maximum increased in maize grain yield was observed by seed treatment of P. fluorescens @ $10 \mathrm{~g} / \mathrm{kg}$ of seed (19.87\%) over than control $(10.98 \%)$, where as foliar spray of Kresoxim-methyl 44.3 SC @ 1 g/l of water $(21.33 \%)$ was also increased maize grain yield over the control (Table 3 ). The interaction of seed treatments with foliar application, P. fluorescens @ $10 \mathrm{~g} / \mathrm{kg}$ of seed followed by two spray of Kresoxim-methyl 44.3 SC @ $1 \mathrm{~g} / \mathrm{l}$ of water increased maize grain yield by $25.63 \%$ over the control $(0.00 \%)$ followed by P. fluorescens @ 10 $\mathrm{g} / \mathrm{kg}$ of seed followed by two spray of Pyraclostrobin 23.6 EC @ 1 g/l of water (24.22\%).

The yield of fodder was also significantly differed for seed treatment chemicals and biocontrol agents and chemicals of foliar applications (Table 4). Yield of fodder were ranging $9.25 \mathrm{t} / \mathrm{ha}$ to $7.72 \mathrm{t} / \mathrm{ha}$ after using either seed treatment or foliar application or both with fungicide or biocontrol agent or both. Seed treatment has significant difference on fodder yield. Maximum fodder yield was observed as $8.76 \mathrm{t} / \mathrm{ha}$ after seed treatment with P. fluorescens @ $10 \mathrm{~g} / \mathrm{kg}$ of seed over the control (7.68 t/ha) was statistically on par with Carboxin $36.5 \%+$ Thiram 36.5\% DS @ $2.5 \mathrm{~g} / \mathrm{kg}$ of seed (8.21 t/ha) and Carbendazim 50 WP @ $2.5 \mathrm{~g} / \mathrm{kg}$ of seed $(8.19 \mathrm{t} / \mathrm{ha})$. Yield of fodder was ranging from $8.23 \mathrm{t} / \mathrm{ha}$ to $8.08 \mathrm{t} / \mathrm{ha}$ by using foliar application one new fungicide. Maximum fodder yield was observed as $8.23 \mathrm{t} / \mathrm{ha}$ after foliar application of Kresoxim-methyl 44.3 SC @ $1 \mathrm{~g} / \mathrm{l}$ of water over the control (7.85 t/ha) was statistically on par with Pyraclostrobin 23.6 EC @ 1 g/l of water (8.16 t/ha) and Pyraclostrobin $5+$ Metiram 55 WG @ $2 \mathrm{~g} / \mathrm{l}$ of water $(8.08 \mathrm{t} / \mathrm{ha})$. Yield of fodder was significant differed for interaction effect of seed treatment and foliar spray also. Maximum fodder yield was observed as 9.25 t/ha with seed treatment with $P$. fluorescens @ $10 \mathrm{~g} / \mathrm{kg}$ of seed followed by two spray of Kresoxim-methyl 44.3 SC @ 1 g/l of water over the control $(7.33 \mathrm{t} / \mathrm{ha})$ was statistically on par with seed treatment with $P$. fluorescens (a $10 \mathrm{~g} / \mathrm{kg}$ of seed followed by two spray of 
Pyraclostrobin 23.6 EC @ 1 g/l of water (8.69 t/ha), seed treatment with $P$. fluorescens @ 10 $\mathrm{g} / \mathrm{kg}$ of seed followed by two spray of followed by two spray of Pyraclostrobin $5+$ Metiram 55 WG @ $2 \mathrm{~g} / \mathrm{l}$ of water (8.63 t/ha). Maximum increased in fodder yield was observed by seed treatment of $P$. fluorescens @ $10 \mathrm{~g} / \mathrm{kg}$ of seed $(19.54 \%)$ over than control (4.74\%), where as foliar spray of Kresoxim-methyl 44.3 SC @ 1 g/l of water
$(12.30 \%)$ was also increased fodder yield over the control $(7.11 \%)$ (Table 3). In term of interaction of seed treatments with foliar application, P.fluorescens @ $10 \mathrm{~g} / \mathrm{kg}$ of seed followed by two spray of Kresoxim-methyl 44.3 SC @ $1 \mathrm{~g} / \mathrm{l}$ of water increased fodder yield by $26.19 \%$ over the control $(0.00 \%)$ followed by P.fluorescens @ $10 \mathrm{~g} / \mathrm{kg}$ of seed followed by two spray of Pyraclostrobin 23.6 EC @ $1 \mathrm{~g} / \mathrm{l}$ of water $(18.55 \%)$.

Table.1 Effect of biocontrol agents and fungicides on PDI of BLSB disease as seed treatments $(\mathrm{S})$ or foliar sprays $(\mathrm{F})$

\begin{tabular}{|c|c|c|c|c|c|c|}
\hline \multirow[b]{2}{*}{ Seed treatment } & \multicolumn{5}{|c|}{ Foliar spray } & \multirow[b]{2}{*}{ Mean } \\
\hline & $\begin{array}{l}\text { Kresoxim- } \\
\text { methyl } 44.3 \\
\text { SC }\end{array}$ & $\begin{array}{l}\text { Pyraclostrobin } \\
23.6 \text { EC }\end{array}$ & \multicolumn{2}{|c|}{$\begin{array}{c}\text { Pyraclostrobin } 5 \\
\text { + Metiram } 55 \\
\text { WG }\end{array}$} & $\begin{array}{l}\text { Untreated } \\
\text { control }\end{array}$ & \\
\hline P. fluorescens & $32.3(34.65)$ & $33.5(35.38)$ & \multicolumn{2}{|c|}{$34.6(36.05)$} & $59.4(50.44)$ & $40.0(39.22)$ \\
\hline T. harzianum & $35.9(36.83)$ & $37.1(37.54)$ & \multicolumn{2}{|c|}{$38.2(38.19)$} & $62.1(52.03)$ & $43.3(41.18)$ \\
\hline Tebucanazole 50 WG & $34.1(35.75)$ & $35.3(36.47)$ & \multicolumn{2}{|c|}{$36.4(37.13)$} & $60.1(50.85)$ & $41.5(40.11)$ \\
\hline Untreated Control & $39.5(38.96)$ & $40.7(39.66)$ & \multicolumn{2}{|c|}{$41.8(40.30)$} & $65.4(54.00)$ & $46.9(43.22)$ \\
\hline $\begin{array}{l}\text { Carboxin } 36.5 \%+ \\
\text { Thiram } 36.5 \%\end{array}$ & $33.8(35.57)$ & $35(36.29)$ & \multicolumn{2}{|c|}{$36.1(36.95)$} & $60.0(50.79)$ & $41.2(39.97)$ \\
\hline Carbendazim 50 WP & $33.8(35.99)$ & $35(36.29)$ & \multicolumn{2}{|c|}{$36.1(36.95)$} & $60.0(50.79)$ & $41.2(39.97)$ \\
\hline $\begin{array}{l}\text { Mencozeb 50\% + } \\
\text { Carbendazim 25\% }\end{array}$ & $34.5(35.57)$ & $35.7(36.71)$ & \multicolumn{2}{|c|}{$36.8(37.37)$} & $60.6(51.15)$ & $41.9(40.36)$ \\
\hline naeM & $34.8(36.19)$ & $36.1(36.91)$ & \multicolumn{2}{|c|}{$37.1(37.57)$} & $61.1(51.43)$ & \\
\hline \multicolumn{2}{|c|}{ For comparison of mean } & \multicolumn{2}{|c|}{ Seed treatments $(\mathrm{S})$} & \multicolumn{2}{|c|}{ Foliar Spray $(\mathrm{F})$} & $\mathrm{S} \times \mathrm{F}$ \\
\hline \multicolumn{2}{|c|}{ S.Em \pm} & \multicolumn{2}{|l|}{0.27} & \multicolumn{2}{|c|}{0.32} & 0.42 \\
\hline \multicolumn{2}{|c|}{ C.D.at $5 \%$} & \multicolumn{2}{|l|}{0.76} & \multicolumn{2}{|c|}{0.90} & 1.18 \\
\hline
\end{tabular}

Table.2 Effect of biocontrol agents and fungicides on percentage disease control of BLSB disease as seed treatments $(\mathrm{S})$ or foliar sprays $(\mathrm{F})$

\begin{tabular}{|l|c|c|c|c|c|}
\hline \multirow{2}{*}{ Seed treatment } & \multicolumn{5}{|c|}{ Foliar spray } \\
\cline { 2 - 6 } & $\begin{array}{l}\text { Kresoxim- } \\
\text { methyl 44.3 SC }\end{array}$ & $\begin{array}{l}\text { Pyraclostrobin } \\
\text { 23.6 EC }\end{array}$ & $\begin{array}{l}\text { Pyraclostrobin 5 + } \\
\text { Metiram 55 WG }\end{array}$ & $\begin{array}{l}\text { Untreated } \\
\text { control }\end{array}$ & Mean \\
\hline P. fluorescens & 50.61 & 48.78 & 47.09 & 9.17 & 38.91 \\
\hline T. harzianum & 45.11 & 43.27 & 41.59 & 5.05 & 33.75 \\
\hline Tebucanazole 50 WG & 48.32 & 46.48 & 44.80 & 8.26 & 36.96 \\
\hline Untreated Control & 39.60 & 37.77 & 36.09 & 0.00 & 28.36 \\
\hline Carboxin 36.5 \% + Thiram 36.5 \% & 47.86 & 46.02 & 44.34 & 8.10 & 36.58 \\
\hline Carbendazim 50 WP & 48.32 & 46.48 & 44.80 & 8.26 & 36.96 \\
\hline Mencozeb 50\% + Carbendazim 25\% & 47.25 & 45.41 & 43.73 & 7.34 & 35.93 \\
\hline naeM & 46.72 & 44.89 & 43.21 & 6.60 & \\
\hline
\end{tabular}


Table.3 Effect of biocontrol agents and fungicides on grain yield $(\mathrm{GY})$ of maize $(\mathrm{q} / \mathrm{ha})$ and increase grain yield (IGY) (\%) of BLSB disease as seed treatments (S) or foliar sprays (F)

\begin{tabular}{|c|c|c|c|c|c|c|c|c|c|c|}
\hline \multirow[t]{3}{*}{ Seed treatment } & \multicolumn{10}{|c|}{ Foliar spray } \\
\hline & \multicolumn{2}{|c|}{$\begin{array}{l}\text { Kresoxim- } \\
\text { methyl } 44.3 \\
\text { SC }\end{array}$} & \multicolumn{2}{|c|}{$\begin{array}{c}\text { Pyraclostrobin } \\
23.6 \text { EC }\end{array}$} & \multicolumn{2}{|c|}{$\begin{array}{c}\text { Pyraclostrobin } \\
5+\text { Metiram } \\
55 \mathrm{WG}\end{array}$} & \multicolumn{2}{|c|}{$\begin{array}{l}\text { Untreated } \\
\text { control }\end{array}$} & \multicolumn{2}{|c|}{ Mean } \\
\hline & GY & IGY & GY & IGY & GY & IGY & GY & IGY & GY & IGY \\
\hline P. fluorescens & 70.54 & 25.63 & 69.75 & 24.22 & 68.42 & 21.85 & 60.53 & 7.80 & 67.31 & 19.87 \\
\hline T. harzianum & 67.14 & 19.57 & 66.35 & 18.17 & 65.02 & 15.80 & 58.60 & 4.36 & 64.28 & 14.47 \\
\hline Tebucanazole 50 WG & 67.74 & 20.64 & 66.95 & 19.23 & 65.62 & 16.87 & 59.55 & 6.06 & 64.97 & 15.70 \\
\hline Untreated Control & 65.34 & 16.37 & 64.55 & 14.96 & 63.22 & 12.59 & 56.15 & 0.00 & 62.32 & 10.98 \\
\hline $\begin{array}{l}\text { Carboxin } 36.5 \%+ \\
\text { Thiram 36.5\% }\end{array}$ & 69.04 & 22.96 & 68.25 & 21.55 & 66.92 & 19.18 & 60.75 & 8.19 & 66.24 & 17.97 \\
\hline Carbendazim 50 WP & 68.74 & 22.42 & 67.95 & 21.02 & 66.62 & 18.65 & 60.65 & 8.01 & 65.99 & 17.52 \\
\hline $\begin{array}{l}\text { Mencozeb 50\% + } \\
\text { Carbendazim 25\% }\end{array}$ & 68.34 & 21.71 & 67.55 & 20.30 & 66.22 & 17.93 & 60.05 & 6.95 & 65.54 & 16.72 \\
\hline naeM & 68.13 & 21.33 & 67.34 & 19.92 & 66.01 & 17.55 & 59.47 & 5.91 & & \\
\hline \multicolumn{3}{|c|}{ For comparison of mean } & \multicolumn{3}{|c|}{ Seed treatments $(\mathrm{S})$} & \multicolumn{3}{|c|}{ Foliar Spray (F) } & \multicolumn{2}{|c|}{$\mathrm{S} \times \mathrm{F}$} \\
\hline \multicolumn{3}{|c|}{ S.Em \pm} & \multicolumn{3}{|c|}{0.32} & \multicolumn{3}{|c|}{0.48} & \\
\hline \multicolumn{3}{|c|}{ C.D.at 5\% } & \multicolumn{3}{|c|}{0.90} & \multicolumn{3}{|c|}{1.34} & \multicolumn{2}{|c|}{1.88} \\
\hline
\end{tabular}

Table.4 Effect of biocontrol agents and fungicides on fodder yield (FY) of maize (t/ha) and increase fodder yield (IFY) (\%) of BLSB disease as seed treatments (S) or foliar sprays (F)

\begin{tabular}{|c|c|c|c|c|c|c|c|c|c|c|}
\hline \multirow[t]{3}{*}{ Seed treatment } & \multicolumn{10}{|c|}{ Foliar spray } \\
\hline & \multicolumn{2}{|c|}{$\begin{array}{l}\text { Kresoxim- } \\
\text { methyl } 44.3 \\
\text { SC }\end{array}$} & \multicolumn{2}{|c|}{$\begin{array}{l}\text { Pyraclostrobin } \\
23.6 \text { EC }\end{array}$} & \multicolumn{2}{|c|}{$\begin{array}{l}\text { Pyraclostrobin } \\
5+\text { Metiram } 55 \\
\text { WG }\end{array}$} & \multicolumn{2}{|c|}{$\begin{array}{l}\text { Untreated } \\
\text { control }\end{array}$} & \multicolumn{2}{|c|}{ Mean } \\
\hline & FY & IFY & FY & IFY & FY & IFY & FY & IFY & FY & IFY \\
\hline P. fluorescens & 9.25 & 26.19 & 8.69 & 18.55 & 8.63 & 17.74 & 8.48 & 15.69 & 8.76 & 19.54 \\
\hline T. harzianum & 7.93 & 8.19 & 7.81 & 6.55 & 7.74 & 5.59 & 7.59 & 3.55 & 7.77 & 5.97 \\
\hline Tebucanazole 50 WG & 8.06 & 9.96 & 8.02 & 9.41 & 7.87 & 7.37 & 7.72 & 5.32 & 7.92 & 8.01 \\
\hline Untreated Control & 7.52 & 2.59 & 7.98 & 8.87 & 7.88 & 7.5 & 7.33 & 0 & 7.68 & 4.74 \\
\hline $\begin{array}{l}\text { Carboxin 36.5 \% + } \\
\text { Thiram 36.5\% }\end{array}$ & 8.37 & 14.19 & 8.24 & 12.41 & 8.18 & 11.6 & 8.03 & 9.55 & 8.21 & 11.94 \\
\hline Carbendazim 50 WP & 8.32 & 13.51 & 8.24 & 12.41 & 8.22 & 12.14 & 7.98 & 8.87 & 8.19 & 11.73 \\
\hline $\begin{array}{l}\text { Mencozeb 50\% + } \\
\text { Carbendazim 25\% }\end{array}$ & 8.17 & 11.46 & 8.12 & 10.78 & 8.06 & 9.96 & 7.83 & 6.82 & 8.05 & 9.75 \\
\hline naeM & 8.23 & 12.30 & 8.16 & 11.28 & 8.08 & 10.27 & 7.85 & 7.11 & & \\
\hline \multicolumn{3}{|c|}{ For comparison of mean } & \multicolumn{3}{|c|}{ Seed treatments $(\mathrm{S})$} & \multicolumn{3}{|c|}{ Foliar Spray $(\mathrm{F})$} & \multicolumn{2}{|c|}{$\mathrm{S} \times \mathrm{F}$} \\
\hline \multicolumn{3}{|c|}{ S.Em \pm} & \multicolumn{3}{|c|}{0.21} & \multicolumn{3}{|c|}{0.32} & \multicolumn{2}{|c|}{0.42} \\
\hline \multicolumn{3}{|c|}{ C.D.at 5\% } & \multicolumn{3}{|c|}{0.59} & \multicolumn{3}{|c|}{0.90} & \multicolumn{2}{|c|}{1.18} \\
\hline
\end{tabular}


Table.5 Effect of biocontrol agents and fungicides on 100 seed weight $(\mathrm{g})$ of BLSB disease as seed treatments $(\mathrm{S})$ or foliar sprays $(\mathrm{F})$

\begin{tabular}{|c|c|c|c|c|c|c|}
\hline \multirow[t]{2}{*}{ Seed treatment } & \multicolumn{6}{|c|}{ Foliar spray } \\
\hline & $\begin{array}{l}\text { Kresoxim- } \\
\text { methyl } 44.3 \text { SC }\end{array}$ & $\begin{array}{l}\text { Pyraclostrobin } \\
23.6 \text { EC }\end{array}$ & & $\begin{array}{l}\text { clostrobin } 5+ \\
\text { tiram } 55 \mathrm{WG}\end{array}$ & $\begin{array}{l}\text { Untreated } \\
\text { control }\end{array}$ & Mean \\
\hline P. fluorescens & 35.42 & 33.45 & & 32.45 & 29.44 & 32.69 \\
\hline T. harzianum & 30.92 & 28.95 & & 27.95 & 24.04 & 27.97 \\
\hline Tebucanazole 50 WG & 32.22 & 30.25 & & 29.25 & 25.34 & 29.27 \\
\hline Untreated Control & 28.72 & 26.75 & & 25.75 & 22.60 & 25.96 \\
\hline $\begin{array}{l}\text { Carboxin } 36.5 \% \text { + Thiram } \\
36.5 \%\end{array}$ & 34.68 & 32.71 & & 31.71 & 27.34 & 31.61 \\
\hline Carbendazim 50 WP & 34.61 & 32.64 & & 31.64 & 27.24 & 31.53 \\
\hline $\begin{array}{l}\text { Mencozeb 50\% + } \\
\text { Carbendazim 25\% }\end{array}$ & 31.42 & 29.45 & & 28.45 & 25.32 & 28.66 \\
\hline naeM & 32.57 & 30.60 & & 29.60 & 25.90 & \\
\hline \multicolumn{2}{|c|}{ For comparison of mean } & \multicolumn{4}{|c|}{ Foliar Spray $(\mathrm{F})$} & $\mathrm{S} \times \mathrm{F}$ \\
\hline \multicolumn{2}{|c|}{ S.Em \pm} & \multicolumn{2}{|l|}{0.51} & \multicolumn{2}{|c|}{0.67} & 0.89 \\
\hline \multicolumn{2}{|l|}{ C.D.at $5 \%$} & \multicolumn{2}{|l|}{1.43} & \multicolumn{2}{|c|}{1.88} & 2.49 \\
\hline
\end{tabular}

The 100 seed weight of maize was also significantly different for seed treatment chemicals and bio-control agents and chemicals of foliar applications (Table 5). Seed treatment has significant difference on 100 seed weight. Maximum 100 seed weight was observed as $32.69 \mathrm{~g}$ after seed treatment with P.fluorescens@10 g/kg of seed over the control $(25.29 \mathrm{~g})$ was statistically on par with Carboxin 36.5\% + Thiram 36.5\% DS @ $2.5 \mathrm{~g} / \mathrm{kg}$ of seed $(31.61 \mathrm{~g})$ and Carbendazim 50 WP @ $2.5 \mathrm{~g} / \mathrm{kg}$ of seed (31.53 g). 100 seed weight was ranging from $32.57 \mathrm{~g}$ to $29.60 \mathrm{~g}$ by using foliar application one new fungicide. Maximum 100 seed weight was observed as $32.57 \mathrm{~g}$ after foliar application of Kresoxim-methyl 44.3 SC @ 1 g/l of water over the control $(25.90 \mathrm{~g})$ followed by Pyraclostrobin 23.6 EC @ 1 g/l of water $(30.60 \mathrm{~g}) .100$ seed weight was significant differed for interaction effect of seed treatment and foliar spray also. Maximum 100 seed weight was observed as $35.42 \mathrm{~g}$ with seed treatment with $P$. fluorescens @ $10 \mathrm{~g} / \mathrm{kg}$ of seed followed by two spray of Kresoximmethyl 44.3 SC @ 1 g/l of water over the control (22.60 g) was statistically on par with seed treatment with Carboxin 36.5\% + Thiram 36.5\% DS @ $2.5 \mathrm{~g} / \mathrm{kg}$ of seed followed by two spray of Kresoxim-methyl 44.3 SC @ 1 g/l of water (34.68 g), seed treatment with Carbendazim 50 WP @ $2.5 \mathrm{~g} /$ $\mathrm{kg}$ of seed followed by two spray of followed by two spray of Kresoxim-methyl 44.3 SC @ $1 \mathrm{~g} / \mathrm{l}$ of water $(34.61 \mathrm{~g})$, seed treatment with P.fluorescens@10 g/kg of seed followed by two spray of Pyraclostrobin 23.6 EC @ 1 g/l of water (33.45 g).

Maximum maize grain yield (67.31 q/ha), fodder yield (8.76 t/ha), 100 seed weight (32.69 g) was obtained by seed treatment of maize with P. fluorescens @ $10 \mathrm{~g} / \mathrm{kg}$ of seed with minimum PDI $40.0 \%$. Seed treatment with Carbendazim 50 WP @ $2.5 \mathrm{~g} / \mathrm{kg}$ of seed and Carboxin 36.5\% + Thiram 36.5\% DS @ $2.5 \mathrm{~g} / \mathrm{kg}$ of seed also found excellent over the control. Similarly Rajput and Harlapur 2015 found that seed treatment with $P$. fluorescens @ $10 \mathrm{~g} / \mathrm{kg}$ of seed also reduce BLSB severity by $49.95 \%$ over the control $38.97 \%$. Seed treatment with carbendazim $(2 \mathrm{~g} / \mathrm{kg}$ of seed $)$ reduced BLSB disease severity by 68.00 percent as compared to control (Akhtar et al., 
2011). Seed treatment with Pseudomonas sp @ $10 \mathrm{~g} / \mathrm{kg}$ of seed also reduced BLSB disease severity by $27 \%$ over the control and enhanced yield of maize as compared to control (Venkateswarlu and Beura, 2020). Strain of $P$. fluorescens BNM296 was also reported to produce $\mathrm{HCN}$ and seed treatment reduces the damping off disease in soybean caused by Pythium ultimum (Leon et al., 2009). Similarly, after co-inoculation of $P$. aureofaciens $63-28$ with $R$. solani, PR protein such as b-1,3-glucanase (PR2), peroxidas (PR 9), chitinases (PR 3) were induced apart from several cell wall degradation enzymes (Jung et al., 2007).

Maximum maize yield (68.13 q/ha), fodder yield (8.23 t/ha), 100 seed weight $(32.57 \mathrm{~g})$ was obtained by foliar spray of Kresoximmethyl 44.3 SC @ $1 \mathrm{~g} / \mathrm{l}$ of water with minimum PDI $46.72 \%$. This result is accordance with Raji et al., 2016, they found that foliar spray of Kresoxim-methyl inhibited growth on $R$. solani in field condition and reduce sheath blight severity with $39.76 \%$. Similarly, Ram (2016) also found Kresoximmethyl as effective fungicide for management of $R$. solani in rice field. Kumar and Ladha (2011) also evaluate the fungicidal property of Kresoxim-methyl against sheath blight of direct seeded rice and found effective. Biswas (2012) also found similar effect as two foliar spray of Kresoxim-methyl along with Hexaconazole effective control $R$. solani in rice field and increase yield also.

Maximum maize yield (70.54 q/ha), fodder yield (9.25 t/ha), 100 seed weight (35.42 g) was obtained by seed treatment with $P$. fluorescens@10 g/kg of seed followed by two spray of Kresoxim-methyl 44.3 SC @ 1 $\mathrm{g} / \mathrm{l}$ of water with minimum PDI $32.3 \%$ followed by seed treatment with $P$. fluorescens@10 g/kg of seed followed by two spray of Pyraclostrobin 23.6 EC @ 1 g/l of water. Integrate disease management is best approach for managing BLSB disease of maize, biocontrol agent such as $P$. fluorescens reduce of soil borne disease caused by $R$. solani through various mechanisms such as DAPG antibiotic production, competition for organic nutrient, production of siderophore, chitinase enzyme, hydrogen cyanide induction of ISR (Rajput 2013). Need based foliar application of Kresoxim-methyl or Pyraclostrobin also manage BLSB disease by blocking transfer of electron in mitochondrial respiratory bc1 complex through attaching with ubihydroquinone oxidation protein (Herms et al., 2002).

\section{References}

Akhtar, J., Kumar, V., Rani, K.T., and Lal, H. C. 2011. Integrated management of banded leaf and sheath blight disease of maize. Plant Disease Research. 25: 35-38.

Biswas, A. 2012. Evaluation of new fungicide formulations against sheath blight disease of rice. Pestology. 36(8): 33-35.

Herms, S., Seehaus, K., Koehle, H., and Conrath, U. 2002. A strobilurin fungicide enhances the resistance of tobacco against tobacco mosaic virus and Pseudomonas syringae pv tabaci. Plant Physiology. 130(1): 120-127.

Jung, W. J., Fazli, M., Kim, T., and Smith, D. 2007. Induction of pathogenesis-related proteins during biocontrol of Rhizoctonia solani with Pseudomonas aureofaciens in soybean (Glycine $\max$ L. Merr.) plants. BioControl. 52: 895-904.

Kumar, V., and Ladha, J. K. 2011. Direct Seeding of Rice: Recent Developments and Future Research Needs. Advances in Agronomy, 111: 0065-2113 DOI:10.1016/B978-0-12-3876898.00001-1.297413.

Lal, S., Baruah, P., and Butchaiah, K. 1980. Assessment of yield losses in maize cultivars due to banded sclerotial disease. Indian Phytopathology. 33: 440-443.

Leon, M., Yaryura, P. M., Montecchia, M. S., Hernandez, A. I., Correa, O. S., Pucheu, 
N. L., Kerber, N. L., and Garcia, A. F. 2009. Antifungal activity of selected indigenous Pseudomonas and Bacillus from the soybean rhizosphere. International Journal of Microbiology. 572049. DOI: 10.1155/2009/572049.

Madhavi, G. B., and Devi, G. U. 2018. Effect of combined application of biofumigant, Trichoderma harzianum and Pseudomonas fluorescens on Rhizoctonia solani f.sp. sasakii. Indian Phytopathology. 71: 257-263. https://doi.org/10.1007/s42360-018-00396

Malik, V. K., Manjeet, S., Hooda, K. S., Yadav, N. K., and Chauhan, P. K. 2018. Efficacy of newer molecules, bioagents and botanicals against maydis leaf blight and banded leaf and sheath blight of maize. Plant Pathology Journal. 34:121-125.

Raji, P., Sumiya, K. V., Dhanya, S., Sheela, M. S., and Narayanankutty, M. C. 2016. Promising fungicides for the management of sheath blight of rice. International Journal of Agricultural Science and Research. 6(1): 273-278.

Rajput, L. S., and Harlapur, S. I. 2014. Status of banded leaf and sheath blight of maize in North Karnataka. Karnataka Journal of Agricultural Science. 27(1): 82-84.

Rajput, L. S., and Harlapur, S. I. 2015. Evaluation of fungicides and biocontrol agents for suppression of banded leaf and sheath blight of maize (Zea mays). Indian Phytopathology. 68(2): 149-155.

Rajput, L. S., and Harlapur, S. I. 2016. Cultural and morphological variability in Rhizoctonia solani causing banded leaf and sheath blight of maize. Indian Journal of Plant Protection. 44(1): 165-167.

Rajput, L. S., Harlapur, S. I., Venkatesh, I., Aggarwal, S. K. and Choudhary, M. 2016a. In vitro study of botanicals and biocontrol agents against Rhizoctonia solani f.sp. sasakii causing banded leaf and sheath blight of maize. International Journal of Agriculture Sciences. 8(53): 2777-27779.

Rajput, L. S., Harlapur, S. I., Venkatesh, I., Aggarwal, S. K. and Choudhary, M. 2016b. In vitro study of fungicides and an antibiotic against Rhizoctonia solani f.sp. sasakii causing banded leaf and sheath blight of maize. International Journal of Agriculture Sciences. 8(54): 2846-2848.

Rajput, L. S. 2013. Studies on banded leaf and sheath blight of maize caused by Rhizoctonia solani f. sp. sasakii EXNER. M. Sc. Thesis. University of Agricultural Sciences, Dharwad, Karnataka, India.

Ram, Chandra, 2016. Bio-efficacy of fungicides against sheath blight disease of rice caused by Rhizoctonia solani. Journal of Eco-friendly Agriculture. 11(1): 70-73.

Venkateswarlu, B., and Beura, S. K. 2020. Evaluation of selective fungicides and biocontrol agents for suppression of banded leaf and sheath blight of maize (Zea mays). Current Journal of Applied Science and Technology. 39(15): 83-8 https://doi.org/10.9734/cjast/2020/v39i15 30775 .

\section{How to cite this article:}

Rajput, L. S., S. I. Harlapur, S. K. Aggarwal, K. Singh and Choudhary, M. 2020. Integrated Evaluation of New Fungicides and Bioagents for the Management of Banded Leaf and Sheath Blight of Maize. Int.J.Curr.Microbiol.App.Sci. 9(09): 3187-3195. doi: https://doi.org/10.20546/ijcmas.2020.909.394 